\title{
In vitro antischistosomal activity of venom from the Egyptian snake Cerastes cerastes
}

\author{
Ehssan Ahmed Hassan ${ }^{[1]}$, Mohamed Ahmed Abdel-Rahman ${ }^{[1]}$, \\ Mohamed Moussa Ibrahim ${ }^{[1],[2]}$ and Maha Farid Mohamed Soliman ${ }^{[1]}$
}

[1]. Zoology Department, Faculty of Science, Suez Canal University, Ismailia, Egypt.
[2]. Biology Department, Faculty of Science, Al-Baha University, Al-Baha, Saudi Arabia.

\begin{abstract}
Introduction: We studied the potential in vitro antischistosomal activity of Cerastes cerastes venom on adult Schistosoma mansoni worms. Methods: Live specimens of the horned viper snake, C. cerastes were collected from the Aswan Governorate (Egypt). Venom was collected from snakes by manual milking. Worms of S. mansoni were obtained from infected hamsters by perfusion and isolated from blood using phosphate buffer. Mortality rates of worms were monitored after 3 days of exposure to snake venom at $\mathrm{LC}_{50}$ and various sublethal concentrations $(10,5,2.5 \mu \mathrm{g} / \mathrm{ml})$. Scanning electron microscopy was used to investigate tegumental changes in treated worms after exposure to $\mathrm{LC}_{50}$ doses of venom. Results: The $\mathrm{LC}_{50}$ of C. cerastes venom was $21.5 \mu \mathrm{g} / \mathrm{ml}$. The effect of $C$. cerastes venom on Schistosoma worms varied according to their sex. The mortality rate of male and female worms after 48 -h exposure was $83.3 \%$ and $50 \%$ respectively. $\mathrm{LC}_{50}$ of C. cerastes venom induced mild to severe tegumental damage in Schistosoma worms in the form of destruction of the oral sucker, shrinkage and erosion of the tegument, and loss of some tubercle spines. Conclusions: The present study demonstrated that $C$. cerastes venom exerts potential in vitro antischistosomal activity in a time and dose-dependent manner. These results may warrant further investigations to develop novel schistosomicidal agents from C. cerastes snake venom.
\end{abstract}

Keywords: Schistosoma mansoni. Snake venom. Antiparasitic. Surface ultrastructure.

\section{INTRODUCTION}

Schistosomiasis is a major parasitic disease of the tropics, causing acute and long-term clinical syndromes ${ }^{(1)(2)}$. Among schistosomicidal drugs, praziquantel is the drug of choice in most areas of endemicity owing to its superior efficacy ${ }^{(3)}$. A small number of cases of resistance to treatment with praziquantel have been reported, and represent a major barrier to the increasing global attempts to eliminate the public health burden of schistosomiasis ${ }^{(4)}$. Such resistance and the possibility of evolving future resistance highlight the need to develop new schistosomicidal treatments ${ }^{(2)(3)(4)}$.

Previous studies have explored the use of toxins as potential therapeutic agents for treating various conditions such as hypertension ${ }^{(5)(6)}$, thrombosis ${ }^{(7)(8)}$, and cancer ${ }^{(9)(10)(11)(12)(13)(14)}$. Among these studies, the initial interest in snake venom was to evaluate how combat the effects of snakebites in humans and to study how snakebite toxins exert their effects. Crude venoms have also been used in traditional medicine for the treatment of

\footnotetext{
Corresponding author: Prof. Maha F.M. Soliman.

e-mail: maha_soliman@hotmail.com

Received 24 June 2016

Accepted 18 October 2016
}

human disease from the early twentieth century ${ }^{(15)}$. In addition, antiparasitic effects of snake venom have been reported against Leishmania $^{(16)(17)}$, Trypanosoma cruzi ${ }^{(18)(19)}$, and Plasmodium ${ }^{(20)(21)}$ parasites.

Cerastes cerastes (family Viperidae), or the horned viper snake, is a medically important and dangerous species of snake in North Africa, and its venom is characterized by its ability to induce severe cytolytic effects ${ }^{(22)}$. Cerastes cerastes venom is highly toxic, primarily attributable to the activity of various proteolytic enzymes it contains ${ }^{(23)(24)}$. Cerastes cerastes venom also exhibits a range of biological activities including antiangiogenic ${ }^{(25)}$, antitumor ${ }^{(26)}$, antibacterial ${ }^{(27)}$, and antiprotozoal ${ }^{(16)}$ effects. Therefore, the present study was performed to evaluate the in vitro antischistosomal activity of C. cerastes venom on adult Schistosoma mansoni parasitic worms. To the best of our knowledge, this is the first study of its kind and it may lead to further research on the characterization of novel antischistosomal agents from snake venom.

\section{METHODS}

\section{Snake venom collection and preparation}

Live specimens of horned viper snakes, Cerastes cerastes $(\mathrm{n}=10)$, were collected in the Aswan Governorate (Egypt) and identified at the Zoology Department, Faculty of Science, 
Suez Canal University, Ismailia, Egypt. Without harming the snakes, venom was collected by manual milking and all snakes were then returned to their natural habitat. The collected venom was pooled, lyophilized, and stored at $-20^{\circ} \mathrm{C}$ until use.

\section{Ethical considerations}

Hamsters were obtained from the Theodor Bilharz Institute, Giza, Egypt and housed under controlled conditions of humidity and a $12 \mathrm{~h}$ light/dark cycle with free access to food and water. All experimental procedures involving animals were conducted in accordance with the Guide for the Care and Use of Laboratory Animals (http://www.nap.edu/catalog/12910. $\mathrm{html}$ ) and approved by the Research Ethics Committee (Section of Experimental Animals 1/2015) of the Faculty of Science, Suez Canal University, Ismailia, Egypt.

\section{In vitro preparation of worms}

Schistosoma worms were obtained from infected hamsters by perfusion and were isolated from blood using small sieves $(20 \mu$ mesh size) and phosphate buffer. Next, the worms were rapidly washed under sterile laminar flow conditions in Roswell Park Memorial Institute (RPMI) culture medium containing 20\% fetal calf serum, 300mg streptomycin, $300 \mathrm{U}$ penicillin and $160 \mu \mathrm{g}$ gentamicin. Worms were then exposed to a range of sublethal concentrations of snake venom in sterilized tissue culture plates ${ }^{(28)}$.

\section{Determination of $\mathrm{LC}_{50}$}

A stock solution $(500 \mu \mathrm{g} / \mathrm{ml})$ of snake venom was prepared in dimethylsulfoxide (DMSO) and diluted with RPMI 1640 to produce $2 \mathrm{ml}$ of working solution with a final concentration of $100 \mu \mathrm{g} / \mathrm{ml}$. Serial concentrations of $10,20,30,40$ and $50 \mu \mathrm{g} / \mathrm{ml}$, to cover the range of $0-100 \%$ mortality, were used to calculate the lethal concentration $50\left(\mathrm{LC}_{50}\right)$. Mortality rate was calculated as the number of dead worms divided by the total number of worms. $\mathrm{LC}_{50}$ was estimated using the Statistical Package for the Social Sciences (SPSS) statistical program (version 20).

\section{Viability of worms}

Worm viability was evaluated using a stereomicroscope after $24 \mathrm{~h}$ of treatment or for three successive days of treatment to determine the $\mathrm{LC}_{50}$ and sublethal concentrations, respectively. Worms showing no signs of motility for one min, in addition to those showing deformities such as blackening, twisting, and contracting, were considered dead.

\section{Mortality rates of Schistosoma mansoni worms}

Two replicates, each containing three pairs of worms (equal ratio of males and females) were placed in control and test solutions $\left(21.6,10,5\right.$ and $2.5 \mu \mathrm{g} / \mathrm{ml}$ of venom) at $37^{\circ} \mathrm{C}^{(29)}$.

\section{Electron microscopy}

Treated worms were fixed with $4 \%$ glutaraldehyde in $0.2 \mathrm{M}$ sodium cacodylate buffer $(\mathrm{pH} 7.3$ ) for $4 \mathrm{~h}$, followed by postfixation in osmium tetraoxide $\left(\mathrm{OSO}_{4}\right)$ for $2 \mathrm{~h}$. Next, the worms were rinsed three times in the same buffer and dehydrated through a series of graded ethanol concentrations from 10$100 \%$ for $10 \mathrm{~min}$ in each concentration, except for the final concentration (100\%) (30 min, 10 min per change). Further dehydration was performed by critical point drying in liquid carbon dioxide. Worms were mounted on copper stubs using double-sided adhesive tape, coated with gold using an S150A sputter coater (Edwards, UK), and viewed with a scanning electron microscope (JXA-840A Electron Probe Microanalyzer; JEOL, Tokyo, Japan).

\section{RESULTS}

\section{Mortality rates of S. mansoni worms}

The $\mathrm{LC}_{50}$ of $C$. cerastes venom in $S$. mansoni worms after $24 \mathrm{~h}$ of exposure was $21.6 \mu \mathrm{g} / \mathrm{ml}$. The mortality rates of worms treated with venom at concentrations of $10,20,30,40$, and $50 \mu \mathrm{g} / \mathrm{ml}$ after $24-\mathrm{h}$ exposure were $36.7 \%, 41.7 \%, 57.1 \%, 84.6 \%$, and $100 \%$, respectively (Figure 1).

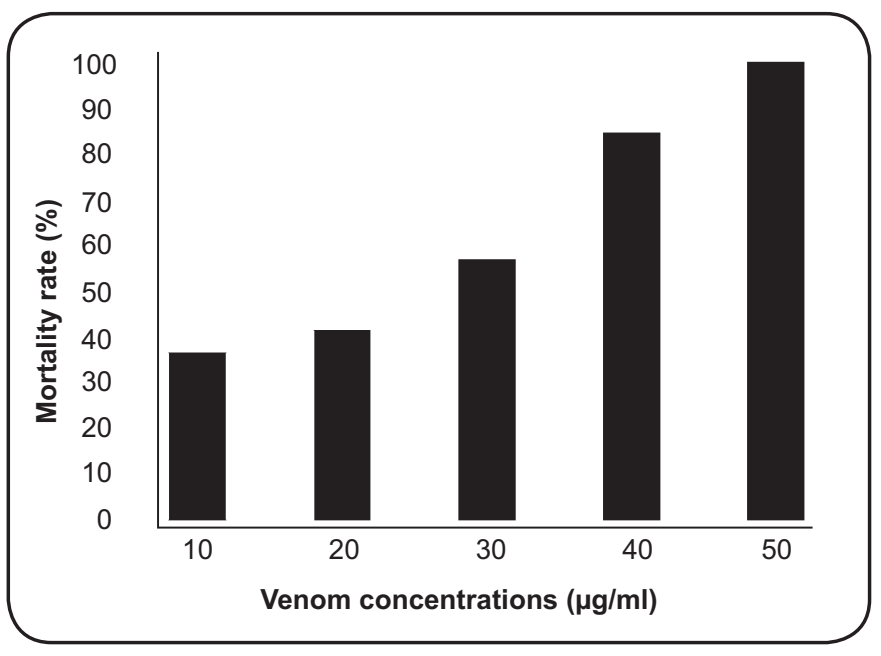

FIGURE 1. Mortality rate of male and female Schistosoma mansoni worms exposed to different concentrations of Cerastes cerastes venom for $24 \mathrm{~h}$ in vitro.

Table 1 shows the mortality rates of $S$. mansoni worms after 3 days of exposure to $\mathrm{LC}_{50}(21.6 \mu \mathrm{g} / \mathrm{ml})$ and sublethal concentrations $(10,5$, and $2.5 \mu \mathrm{g} / \mathrm{ml})$ of venom. Total mortality rates of worms at $\mathrm{LC}_{50}$ were $16.7 \%, 66.7 \%$, and $66.7 \%$ on days 1,2 , and 3 post exposure, respectively. Total mortality rates of worms at concentrations of 10,5 , or $2.5 \mu \mathrm{g} / \mathrm{ml}$ were $8.3 \%$, $15.5 \%$, and $27.4 \% ; 4.2 \%, 8.3 \%$, and $20.8 \%$; and $4.2 \%$ at days 1,2 , and 3 post exposure, respectively. The susceptibility of male and female worms to the venom differed, with male worms being more susceptible than females were to $\mathrm{LC}_{50}$ or to sublethal concentrations $(2.5,5$, and $10 \mu \mathrm{g} / \mathrm{ml})$. In addition, $\mathrm{LC}_{50}$ dose had no effect on female worms after $24 \mathrm{~h}$ but caused $50 \%$ mortality after $48 \mathrm{~h}$. The sublethal concentrations, 10 and $5 \mu \mathrm{g} / \mathrm{ml}$, had no effect on female worms after $24 \mathrm{~h}$ but caused $25 \%$ and $8.3 \%$ mortality among female worms after $72 \mathrm{~h}$, respectively. No mortality was recorded among female worms exposed to $2.5 \mu \mathrm{g} / \mathrm{ml}$ for 3 days, while the mortality rate among male worms under the same conditions was $8.3 \%$. 


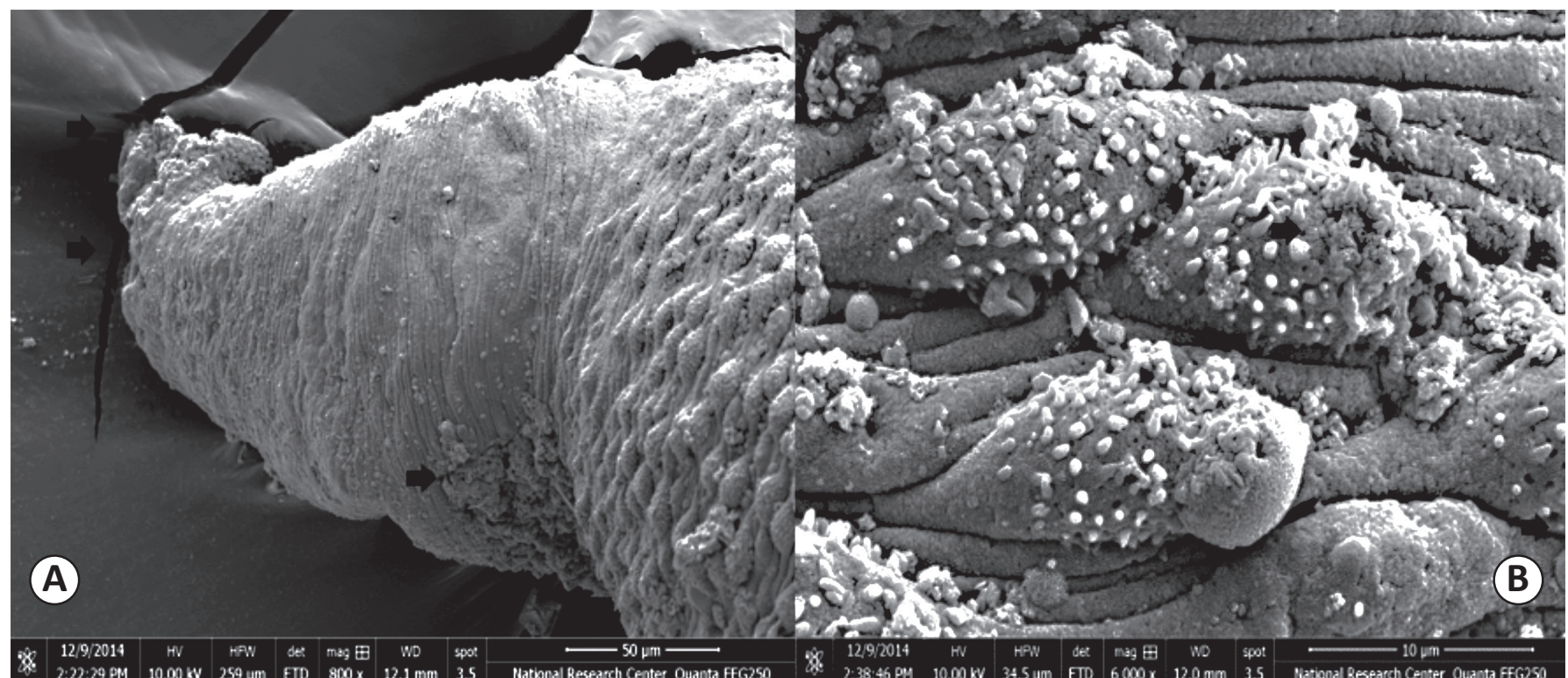

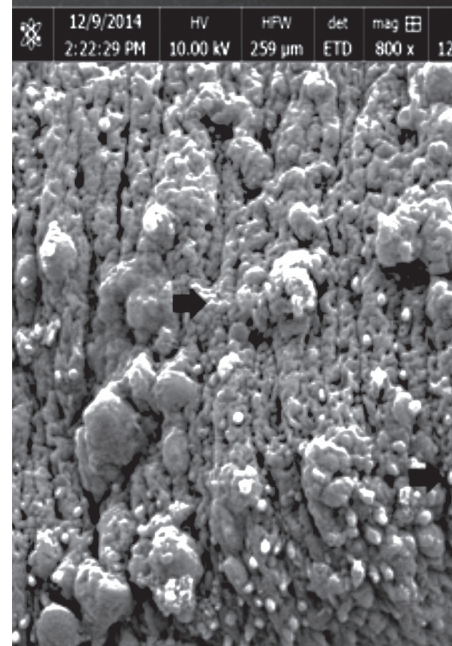

(C)

28 12/9/2014 HV HFW det mos $\Phi$ WD spot

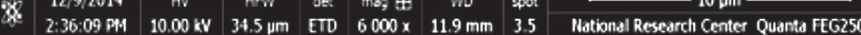

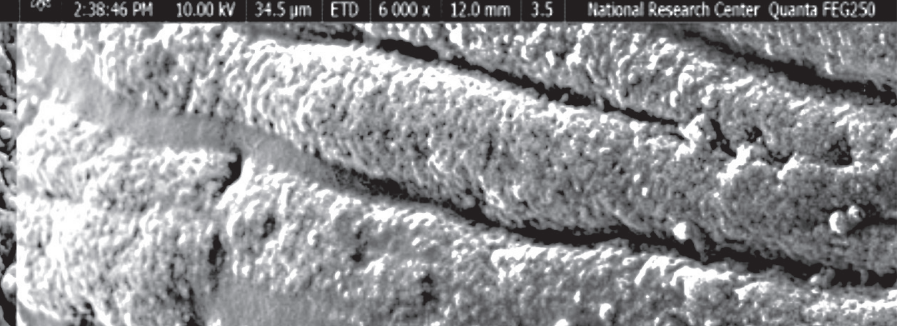

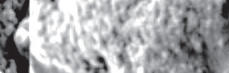

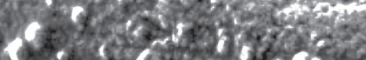
Wowat

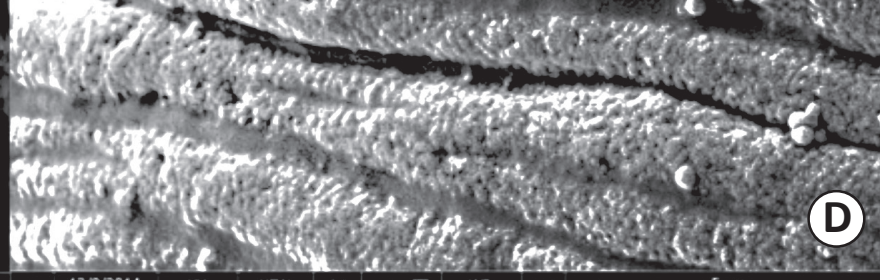

12/9/2014 HV HFW set mag $⿴ 囗 十$ WD spst
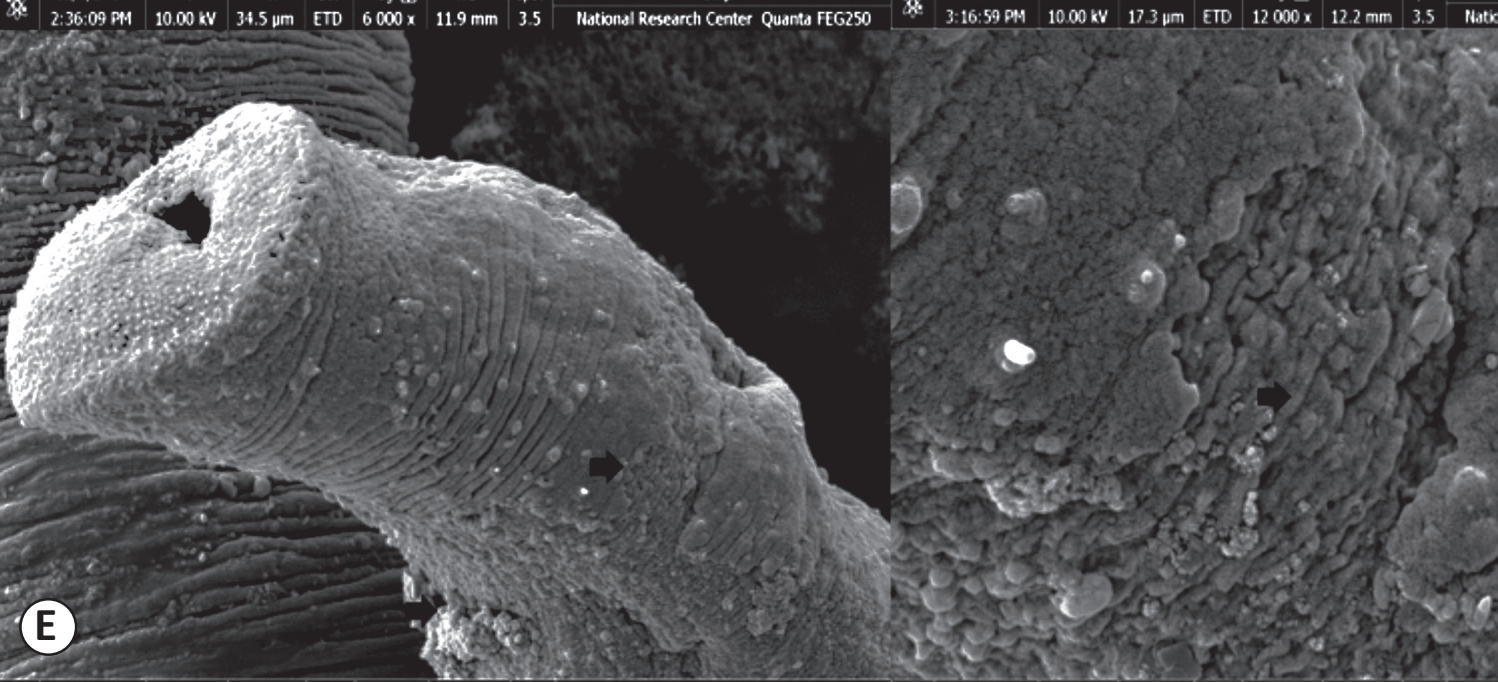

12 12/9/2014 HW HFW set mag

FIGURE 2. Surface ultrastructure alterations in adult male (A-C) and female (D-C) Schistosoma mansoni worms following incubation with $\mathrm{LC}_{50}(21.6 \mu \mathrm{g} / \mathrm{ml})$ of Cerastes cerastes snake venom. Black arrows indicate destruction of the oral sucker and tegument (A), loss and destruction of tubercle spines (B), formation of protuberances and shortening of spines in the tegumental area around the gynaecophoric canal (C), and mild to moderate destruction, shrinkage, and erosion of the tegument of female worms (D-F). $\mathbf{L C}_{50}$ lethal concentration 50. 
TABLE 1

Mortality rate (\%) of Schistosoma mansoni worms exposed to different concentrations of Cerastes cerastes venom for 3 consecutive days in vitro.

\begin{tabular}{|c|c|c|c|c|c|c|c|c|c|}
\hline \multirow[b]{2}{*}{ Concentration of snake venom $(\mu \mathrm{g} / \mathrm{ml})$} & \multicolumn{9}{|c|}{ Mortality rate (\%) } \\
\hline & males & females & total & males & females & total & males & females & total \\
\hline $21.6(\mathrm{LC} 50)$ & 33.3 & 0.0 & 16.7 & 83.3 & 50.0 & 66.7 & 83.3 & 50.0 & 66.7 \\
\hline 10 & 16.7 & 0.0 & 8.3 & 29.2 & 0.0 & 15.5 & 33.3 & 25.0 & 27.4 \\
\hline
\end{tabular}

$\mathbf{L C}_{50}$ : lethal concentration 50 .

\section{Electron microscopy}

Surface ultrastructure alterations were observed in adult male and female $S$. mansoni worms following exposure to $\mathrm{LC}_{50}$ doses of venom (Figure 2). Mild to severe tegumental damage was noted among both male and female worms. In male worms, marked destruction of the oral sucker, shrinkage and erosion of the tegument, loss of several tubercle spines, and formation of protuberances in the gynaecophoric canal tegument were observed (Figures 2A, 2B and 2C). In female worms, mild to moderate shrinkage and erosion of the dorsal and ventral tegument were observed (Figures 2C, 2D and 2F).

\section{DISCUSSION}

To our knowledge, the present study is the first to evaluate the effect of $C$. cerastes venom against $S$. mansoni. The $\mathrm{LC}_{50}$ of C. cerastes venom in S. mansoni worms after 24-h exposure was $21.6 \mu \mathrm{g} / \mathrm{ml}$, a significantly higher dose than that of the reference drug praziquantel $(6,675 \mu \mathrm{g} / \mathrm{ml})^{(30)}$ or of combination artemisinin-naphthoquine phosphate treatment (CO-ArNp) after $72 \mathrm{~h}(7.2 \mu \mathrm{g} / \mathrm{ml})^{(31)}$. In addition, the $\mathrm{LC}_{50}$ against schistosomes of mefloquine and hemin alone was determined to be $6.5 \mu \mathrm{g} / \mathrm{ml}$ and $232 \mu \mathrm{g} / \mathrm{ml}$, respectively, while the $\mathrm{LC}_{50}$ of hemin in the presence of mefloquine $(1 \mu \mathrm{g} / \mathrm{ml})$ was $23.2 \mu \mathrm{g} / \mathrm{ml}^{(32)}$.

Regarding time and dose responses, our results showed that the mortality rates of worms at $\mathrm{LC}_{50}$ ranged from $16.7 \%$ to $66.7 \%$ after $24-72 \mathrm{~h}$ of treatment with venom, while total mortality rates at concentrations of 10,5 , or $2.5 \mu \mathrm{g} / \mathrm{ml}$ ranged from $4.2 \%$ to $27.4 \%$ after $24-72 \mathrm{~h}$ of treatment. Similarly, another

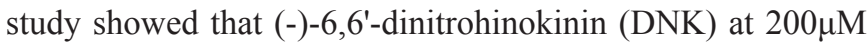
killed $100 \%$ of adult worms within $24 \mathrm{~h}$ and had $\mathrm{LC}_{50}$ values of $103.9 \pm 3.6$ and $102.5 \pm 4.8 \mu \mathrm{M}$ at 24 and $72 \mathrm{~h}$, respectively ${ }^{(33)}$. Incubation of adult $S$. mansoni worms with $\mathrm{CO}-\mathrm{ArNp}$ at $20-40 \mu \mathrm{g} / \mathrm{ml}$ for $48-72 \mathrm{~h}$ also killed all worms ${ }^{(31)}$.

Disparities in drug susceptibility between male and female S. mansoni worms have been previously reported in several in vitro activity trials ${ }^{(34)}$. The results of the present study showed that the susceptibility of male and female worms to venom varied, with male worms being more susceptible than females were. In this regard, male $S$. mansoni worms were also more susceptible than females were to praziquantel, ginger extract, diamines, and amino alcohols and to treatment with certain essential oils ${ }^{(35)(36)(37)(38)(39)}$. However, there was no differential sensitivity to piplartine between male and female worms in vitro $^{(34)}$. In contrast, treatment with other compounds such as amino alkanethiosulfuric acids ${ }^{(4)}, 2$-(butylamino)-1-phenyl1-ethanethiosulfuric acid $^{(41)}$, and artesunate ${ }^{(42)}$ produced higher mortality rates among female $S$. mansoni worms than among males.

Tegumental changes produced by antischistosomal drugs are a necessary mechanism for causing the death of the worm ${ }^{(43)}$. Generally, if a drug induces tegumental alterations, the onset and precise pattern of these alterations depend on the particular drug and the treatment regimen used ${ }^{(44)}$. The characteristic features of tegumental damage observed in this study, including destruction of the tegument and erosion and loss of spines, were consistent with those previously described in the literature following in vitro exposure to different antischistosomal agents such as hypericin ${ }^{(45)}$, allicin ${ }^{(46)}$, nerolidol ${ }^{(47)}$, phthalyl thiazole $(\mathrm{LpQM}-45)^{(48)}, \beta$-lapachone ${ }^{(49)}$, and DNK ${ }^{(32)}$. Hence, reductions in worms may be attributed to the tegumental damage observed.

In conclusion, the present study demonstrated that $C$. cerastes venom exerts potential in vitro antischistosomal activity against $S$. mansoni in a time- and dose-dependent manner. Further studies are needed, however, to characterize the active compounds present in the venom and their cytotoxic effects for potential use in the future development of novel therapeutic agents.

\section{Conflict of interest}

The authors declare that there is no conflict of interest.

\section{REFERENCES}

1. Coltart C, Whitty CJ. Schistosomiasis in non-endemic countries. Clin Med 2015; 15:67-69.

2. Deribew K, Tekeste Z, Petros B. Urinary schistosomiasis and malaria associated anemia in Ethiopia. Asian Pac J Trop Biomed 2013; 3:307-310.

3. El Ridi R, Aboueldahab M, Tallima H, Salah M, Mahana N, Fawzi, $\mathrm{S}$, et al. In vitro and in vivo activities of arachidonic acid against 
Schistosoma mansoni and Schistosoma haematobium. Antimicrob Agents Chemother 2010; 54:3383-3389.

4. CowanN, YaremenkoIA,KrylovIB, Terent'evAO,KeiserJ.Elucidation of the in vitro and in vivo activities of bridged 1,2,4-trioxolanes, bridged 1,2,4,5-tetraoxanes, tricyclic monoperoxides, silyl peroxides, and hydroxylamine derivatives against Schistosoma mansoni. Bioorg Med Chem 2015; 23:5175-5781.

5. Soares AM. Use of snake venom for biomedical researches and drug development. SOAJ Biochem Biotechnol 2012; 1:1-4.

6. Ettinger K, Cohen G, Momic T, Lazarovici P. The effects of a chactoid scorpion - venom and its purified toxins on rat blood pressure and mast cells histamine release. Toxins 2013; 5:1332-1342.

7. Matsui T, Fujimura Y, Titani K. Snake venom proteases affecting hemostasis and thrombosis. Biochem Biophys Acta 2000; 1477:146156.

8. Goswami U, Brenes JA, Punjabi GV, LeClaire MM, Williams DN. Associations and outcomes of septic pulmonary embolism. Open Respir Med J 2014; 8:28-33.

9. Deshane J, Garner CC, Sontheimer H. Chlorotoxin inhibits glioma cell invasion via matrix metalloproteinase-2. J Biol Chem 2003; 278:4135-4144.

10. Aarti C, Khusro A. Snake venom as anticancer agent current perspective. Int J Pure Appl Biosci 2013; 1:24-29.

11. Abdel-Rahman MA, Abdel-Nabi M, El-Naggar MS, Abbas OA, Strong PN. Conus vexillum venom induces oxidative stress in Ehrlich's ascites carcinoma cells: an insight into the mechanism of induction. J Venom AnimToxins Incl Trop Dis 2013; 19:10.

12. Zouari-Kessentini R, Srairi-Abid N, Bazaa A, El Ayeb M, Luis J, Marrakchi N. Antitumoral potential of Tunisian snake venoms secreted phospholipases $\mathrm{A}_{2}$. BioMed Res Int 2013; 2013:391389. doi: 10.1155/2013/391389.

13. Calderon LA, Sobrinho JC, Zaqueo KD, de Moura AA, Grabner AN, Mazzi MV, et al. Antitumoral activity of snake venom proteins: new trends in cancer therapy. Bio Med Res Int 2014; 2014:203639. doi: $10.1155 / 2014 / 203639$

14. Sethi S, Ali S, Sethi S, Sarkar FH. MicroRNAs in personalized cancer therapy. Clin Genet 2014; 86:68-73.

15. Koh CY, Kini RM. From snake venom toxins to therapeutics cardiovascular examples. Toxicon 2012; 59:497-506.

16. Peichoto ME, Tavares FL, Dekrey G, Mackessy SP. A comparative study of the effects of venoms from five rear-fanged snake species on the growth of Leishmania major: identification of a protein with inhibitory activity against the parasite. Toxicon 2011; 58:28-34.

17. Bhattacharya S, Ghosh P, De T, Gomes A, Dungdung SR. In vivo and in vitro antileishmanial activity of Bungarus caeruleus snake venom through alteration of immunomodulatory activity. Exp Parasitol 2013; 135:126-133.

18. Lazo F, Málaga O, Yarlequé A, Severino R, Gutiérrez S. Actividad antimicrobiana de una flavoproteína aislada del veneno de la serpiente peruana Bothrops atrox (“jergón”). Rev Soc Quim Peru 2007; 73:197-207.

19. Adade CM, Cons BL, Melo PA, Souto-Padrón T. Effect of Crotalus viridis viridis snake venom on the ultrastructure and intracellular survival of Trypanosoma cruzi. Parasitol 2011; 138:46-58.

20. Deregnaucourt C, Schrével J. Bee venom phospholipase $A_{2}$ induces stage-specific growth arrest of the intraerythrocytic Plasmodium falciparum via modifications of human serum components. J Biol Chem 2000; 275:39973-39980.
21. Castillo JCQ, Vargas LJ, Segura C, Gutiérrez JM, Pérez JCA. In vitro antiplasmodial activity of phospholipases $\mathrm{A}_{2}$ and a phospholipase homologue isolated from the venom of the snake Bothrops asper. Toxins (Basel) 2012; 4:1500-1516.

22. Oukkache N, Lalaoui M, Ghalim N. General characterization of venom from the Moroccan snakes Macrovipera mauritanica and Cerastes cerastes. J Venom Anim Toxins Incl Trop Dis 2012; 18:411-420.

23. Aird SD. Ophidian envenomation strategies and the role of purines. Toxicon 2002; 40:335-393.

24. Warrell DA. Epidemiology, clinical features and management of snakebites in Central and South America. In: Campbell J, Lamar WW, editors. Venomous Reptiles of the Western Hemisphere. Ithaca: Cornell University Press; 2004. p. 709-761.

25. Zouari-Kessentini R, Luis J, Karray A, Kallech-Ziri O, Srairi-Abid $\mathrm{N}$, Bazaa A, et al. Two purified and characterized phospholipases $\mathrm{A}_{2}$ from Cerastes cerastes venom, that inhibit cancerous cell adhesion and migration. Toxicon 2009; 53:444-453.

26. Abu-Sinna G, Esmat AY, Al-Zahaby AA, Soliman NA, Ibrahim TM. Fractionation and characterization of Cerastes cerastes cerastes snake venom and the antitumor action of its lethal and nonlethal fractions. Toxicon 2003; 42:207-215.

27. Hanane-Fadila ZM, Fatima LD. Purification, characterization and antibacterial activity of L-amino acid oxidase from Cerastes cerastes. J Biochem Mol Toxic 2014; 28:347-354.

28. Yousif F, Hifnawy M, Soliman G, Boulos L, Labib Th, Mahmoud S, et al. Large-scale in vitro screening of Egyptian native and cultivate plants for schistosomicidal activity. Pharm Biol 2007; 45:501-510.

29. El Bardicy S, El Sayed I, Yousif F, Van Der Veken P, Haemers A, Augustyns K, et al. Schistosomicidal and molluscicidal activities of amino alkyl amino substituted neo- and norneocryptol epine derivatives. Pharm Biol 2012; 50:134-140.

30. Abou-Shady O, Mohammed S, Attia S, Yusuf H, Helmy D. In vitro effect of mefloquine on adult Schistosoma mansoni. Res J Parasitol 2015; 10:111-119.

31. El-Beshbishi SN, El Bardicy S, Tadros M2 Ayoub M, Taman A. Spotlight on the in vitro effect of artemisinin-naphthoquine phosphate on Schistosoma mansoni and its snail host Biomphalaria alexandrina. Acta Trop 2015; 141:37-45.

32. Xiao SH, Qiao C, Xue J, Wang L. Mefloquine in combination with hemin causes severe damage to adult Schistosoma japonicum in vitro. Acta Trop 2014; 131:71-78.

33. Pereira AC, Silva ML, Souza JM, Laurentiz RS, Rodrigues V, Januário $\mathrm{AH}$, et al. In vitro and in vivo anthelmintic activity of (-)-6,6'-dinitrohinokinin against schistosomula and juvenile and adult worms of Schistosoma mansoni. Acta Trop 2015; 149:195-201.

34. Moraes J, Nascimento C, Lopes POMV, Nakano E, Yamaguchi LF, Kato MJ, et al. Schistosoma mansoni: in vitro schistosomicidal activity of piplartine. Exp Parasitol 2011; 127:357-364.

35. Mostafa OM, Eid RA, Adly MA. Antischistosomal activity of ginger (Zingiber officinale) against Schistosoma mansoni harbored in C57 mice. Parasitol Res 2011; 109:395-403.

36. Pica-Mattoccia L, Cioli D. Sex- and stage-related sensitivity of Schistosoma mansoni to in vivo and in vitro praziquantel treatment. Int J Parasitol 2004; 34:527-533.

37. Tonuci LRS, de Melo NI, Dias HJ, Wakabayashi KAL, Aguiar GP, Aguiar DP, et al. In vitro schistosomicidal effects of the essential oil of Tagetes erecta. Rev Bras Farmacogn 2011; 22:88-93.

38. Fernandes FS, Rezende Júnior CO, Fernandes TS, da Silveira LS, Rezende CAM, de Almeida MV, et al. Anthelmintic effects of 
alkylated diamines and amino alcohols against Schistosoma mansoni. Bio Med Res Int 2013; 2013:783490. doi: 10.1155/2013/783490.

39. de Oliveira RN, Rehder VLG, Santos Oliveira AS, Montanari Júnior I, de Carvalho JE, de Ruiz ALTG, et al. Schistosoma mansoni: in vitro schistosomicidal activity of essential oil of Baccharis trimera (less) DC. Exp Parasitol 2012; 132:135-143.

40. de Oliveira Penido ML, Zech Coelho PM, de Mello RT, Piló-Veloso $\mathrm{D}$, de Oliveira MC, Kusel JR, et al. Antischistosomal activity of amino alkanethiols, amino alkanethiosulfuric acids and the corresponding disulfides. Acta Trop 2008; 108:249-255.

41. de Araújo SC, de Mattos ACA, Teixeira HF, Coelho PMZ, Nelson $\mathrm{DL}$, de Oliveira MC. Improvement of in vitro efficacy of a novel schistosomicidal drug by incorporation into nanoemulsions. Int J Pharm 2007; 337:307-315.

42. Mitsui Y, Miura M, Aoki Y. In vitro effects of artesunate on the survival of worm pairs and egg production of Schistosoma mansoni. J Helminthol 2009; 83:7-11.

43. Shuhua X, Hotez PJ, Tanner M. Artemether, an effective new agent for chemoprophylaxis against schistosomiasis in China: its in vivo effect on the biochemical metabolism of the Asian schistosome. Southeast Asian J Trop Med Public Health 2000; 31:724-732.
44. Shuhua X, Binggui S, Utzinger J, Chollet J, Tanner M. Ultrastructural alterations in adult Schistosoma mansoni caused by artemether. Mem Inst Oswaldo Cruz 2002; 97:717-724.

45. Cai R, She XP, Wang Y, Gong W, Zhang HQ, Xia CM. In vitro effect of photoactivated hypericin on anti-Schistosoma japonicum adult male worms. Zhongguo Ji Sheng Chong Xue Yu Ji Sheng Chong Bing Za Zhi 2014; 32:176-179. PMID 25223049.

46. Lima CMBL, Freitas FIS, de Morais LCSL, Cavalcanti MGS, da Silva LF, Padilha RJR, et al. Ultrastructural study on the morphological changes to male worms of Schistosoma mansoni after in vitro exposure to allicin. Rev Soc Bras Med Trop 2011; 44:327-330.

47. Silva MP, Oliveira GL, de Carvalho RB, de Sousa DP, Freitas RM, Pinto PL, et al. Antischistosomal activity of the terpene nerolidol. Molecules 2014; 19:3793-3803.

48. Santiago EF, de Oliveira SA, de Oliveira Filho GB, Moreira DRM, Gomes PAT, da Silva AL, et al. Evaluation of the anti-Schistosoma mansoni activity of thiosemicarbazones and thiazoles. Antimicrob Agents Chemother 2014; 58:352-363.

49. Aires AL, Ximenes ECPA, Silva RAR, Barbosa VX, Góes AJS, Peixoto CA, et al. Ultrastructural analysis of $\beta$-lapachone-induced surface membrane damage in male adult Schistosoma mansoni $\mathrm{BH}$ strain worms. Exp Parasitol 2014; 142:83-89. 